\title{
Synthesis and characterization of $\mathrm{AgFeO}_{2}$ delafossite with non-stoichiometric silver concentration
}

\author{
Karolina Siedliska, \\ Tomasz Pikula, \\ Dariusz Chocyk, \\ Elżbieta Jartych
}

\begin{abstract}
The simple co-precipitation method was used to prepare $\mathrm{Ag}_{x} \mathrm{FeO}_{2}$ delafossite with non-stoichiometric silver concentration in the range of $x=0.05-1$. The obtained material was investigated using X-ray powder diffraction and ${ }^{57} \mathrm{Fe}$ Mössbauer spectroscopy at room temperature. The structural and hyperfine interaction parameters were recognized in relation with decreasing silver concentration. The study revealed that the delafossite structure of $\mathrm{Ag}_{x} \mathrm{FeO}_{2}$ was maintained up to $x=0.9$; as the range of silver concentration was decreased to $0.05 \leq x \leq 0.8$, a mixture of $\mathrm{AgFeO}_{2}, \mathrm{Fe}_{2} \mathrm{O}_{3}$ or/and $\mathrm{FeOOH}$ was formed.
\end{abstract}

Keywords: delafossite $\bullet$ silver ferrite $\bullet$ co-precipitation $\bullet$ hyperfine interactions $\bullet$ Mössbauer spectroscopy

K. Siedliska ${ }^{\bowtie, \#}$, T. Pikula, E. Jartych Institute of Electronics and Information Technology, Lublin University of Technology,

38A Nadbystrzycka Str., 20-618 Lublin, Poland, Tel.: +48 81538 4464, Fax: +48 81538 4312,

E-mail: k.siedliska@pollub.pl

\#PhD student

D. Chocyk

Department of Applied Physics,

Lublin University of Technology,

36 Nadbystrzycka Str., 20-618 Lublin, Poland

Received: 8 July 2016

Accepted: 8 October 2016

\section{Introduction}

Delafossites are a promising class of materials which have applications as transparent semiconducting oxides, catalysts, luminescent materials, $p$-type semiconductors used in solar cells, optoelectronic devices, transparent photodiodes, batteries [1-7], etc. Even though much work has been carried out on the cuprate family of delafossites, especially about $\mathrm{CuFeO}_{2}$ [8], little is known about the structural, electronic and magnetic properties of its silver counterpart $\mathrm{AgFeO}_{2}$. Silver ferrite is described by the general formula $\mathrm{ABO}_{2}$, where A denotes monovalent cation of semi-noble or noble metal, typically $\mathrm{Cu}^{+}$, $\mathrm{Ag}^{+}, \mathrm{Pd}^{+}$or $\mathrm{Pt}^{+}$, while $\mathrm{B}$ means trivalent cation of: (a) $p$-block element (Al, Ga, In, Tl), (b) transition metal (Cr, Mn, Fe, Co, Ni, Y, Rh) or (c) rare earth element (Sc, La, Nd, Eu) [9]. Many delafossites are also multiferroics, which increase the interest and efforts of researchers to find efficient methods of producing pure compounds of delafossite type [10].

Silver ferrite, $\mathrm{AgFeO}_{2}$, has a layered structure with one layer as the close-packed monovalent Ag ions and the other as edge-shared $\mathrm{Fe}^{3+} \mathrm{O}_{6}$ octahedra with iron cations inside [11]. The $\mathrm{Ag}^{+}$cations are coordinated by two oxygen ions with the linear $\mathrm{O}-\mathrm{Ag}-\mathrm{O}$ bonds. Each $\mathrm{Fe}^{3+}$ cation, located in the slightly distorted oxygen octahedron, is coordinated with six oxygen ions. The delafossite structure can form two polytypes depending on the sequence of stacking of layers $[10,11]$. These are rhombohedral $3 R$ type (space group symmetry $R-3 m$ ) and hexago- 


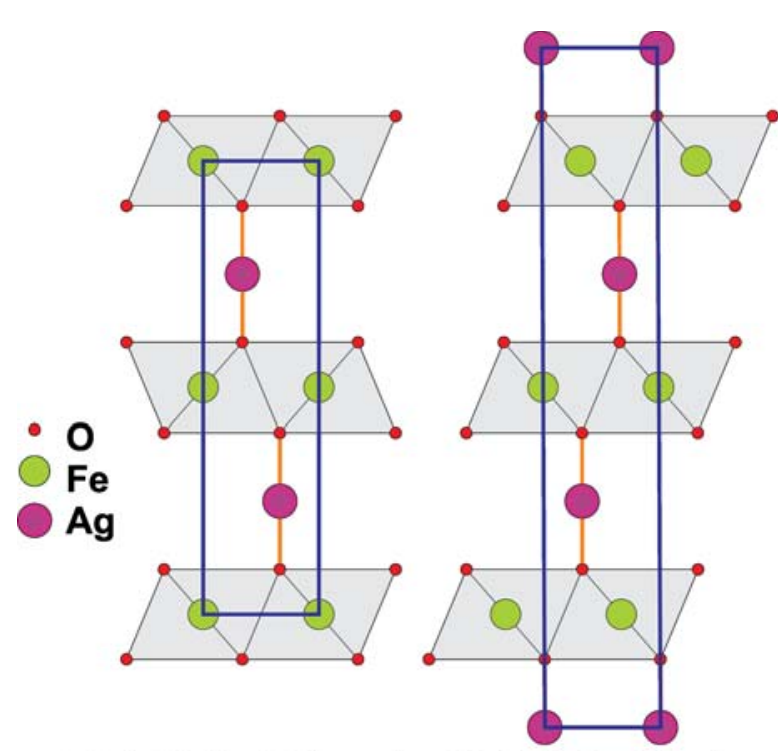

2H-AgFeO ${ }_{2}\left(\mathrm{PG}_{3} / \mathrm{mmc}\right)$ 3R-AgFeO $(R \overline{3} m)$

Fig. 1. Layered delafossite-type crystal structure of $\mathrm{AgFeO}_{2}$. The projection of the unit cell onto an $\mathrm{YZ}$ plane: (a) $2 H$ polytype and (b) $3 R$ polytype.

nal $2 H$ type (space group symmetry $P 6_{3} / m m c$ ) as presented in Fig. 1.

Because of decomposition of silver oxide in air at temperature $573 \mathrm{~K}$ [10], the synthesis of ternary oxides with silver is very difficult and requires special conditions, that is, low temperatures and/or closed systems making it an expensive technology. Among methods of producing silver delafossite materials, it may be distinguished as: (1) low-temperature methods (e.g., hydrothermal synthesis, metathetical reaction, oxidizing flux reaction, sol-gel) [10-14], (2) high-temperature synthesis (e.g., solid-state reaction [15-19]) and (3) thin film techniques (e.g., atomic layer deposition, pulsed laser deposition (PLD), chemical vapour deposition (CVD), RF sputtering [6, 20-22]). However, they do not always allow obtaining compounds of high purity. The co-precipitation method can be used for the preparation of delafossite $\mathrm{AgFeO}_{2}$ without any special conditions, that is, high temperature or pressure. This method with various modifications was employed successfully to prepare silver ferrite, as reported in [2, 23-28]. However, most of these methods allowed obtaining the silver ferrite as a mixture of $3 R$ and $2 \mathrm{H}$ polytypes in various proportions. Both polytypes of silver ferrite could be prepared separately only under special conditions (high-pressure $3 \mathrm{GPa}$ and $6 \mathrm{GPa})$, as shown in $[17,18]$.

In this study, systematic investigations of silver ferrite structure with non-stoichiometric silver concentration were performed. The main objective of these investigations was to observe changes in the physical properties of the obtained material with decreasing amount of $\mathrm{Ag}$. Moreover, a reduction in silver concentration would allow us to lower the cost of producing $\mathrm{AgFeO}_{2}$. The obtained samples were investigated using X-ray diffraction (XRD) and ${ }^{57} \mathrm{Fe}$ Mössbauer spectroscopy (MS) at room temperature. The aim of the present work was to find the relationship between the structure and hyperfine interactions of silver ferrite with lowering of silver concentration.

\section{Experimental details}

The co-precipitation method was used to prepare $\mathrm{Ag}_{x} \mathrm{FeO}_{2}$ silver ferrite series with non-stoichiometric silver concentration in the range $x=0.05-1$, where $x$ was the assumed $\mathrm{Ag}$ content. Silver nitrate $\mathrm{AgNO}_{3}$ and iron nitrate $\mathrm{Fe}\left(\mathrm{NO}_{3}\right)_{3} \cdot 9 \mathrm{H}_{2} \mathrm{O}$ (purity grade 99.99\%) were precursor materials and $\mathrm{NaOH}$ was a precipitation agent. Water solution of iron and silver nitrates was mixed in appropriate proportions, stirred at room temperature, and then heated at $343 \mathrm{~K}$ for $1 \mathrm{~h}$ in a water bath. Next, dilute sodium hydroxide was slowly added to the obtained solution, while constantly stirring with a magnetic stirrer until a pH level of 11-12 was reached. The stirring of aqueous suspensions was continued for aging the precipitates at room temperature for $6 \mathrm{~h}$. Then, the resulting precipitates were collected by sedimentation, washed several times in distilled water and dried at $373 \mathrm{~K}$ overnight. After drying, the series of $\mathrm{Ag}_{x} \mathrm{FeO}_{2}$ samples in colour from brick brown to dingy yellow was obtained. Material in the form of flakes was then powdered in agate mortar.

The crystalline structure of the obtained samples was investigated using the PANalytical-Empyrean diffractometer with $\mathrm{CuK}_{\alpha}$ radiation. The phase and structural analyses of the recorded XRD patterns were performed with the PANalytical X'Pert HighScore Plus computer program equipped with the ICDD PDF database.

${ }^{57} \mathrm{Fe}$ Mössbauer spectra were recorded using POLON spectrometer working in a transmission geometry and constant acceleration mode. $\mathrm{A}^{57} \mathrm{Co}$ in a rhodium matrix was used as a source of $14.4 \mathrm{keV}$ gamma radiation. Measurements were performed at room temperature. All the values of isomer shift within this paper are related to the $\alpha$-Fe standard.

\section{Results and discussion}

\section{Results of X-ray diffraction studies}

X-ray diffraction room temperature studies for stoichiometric $\mathrm{AgFeO}_{2}$ confirmed the obtaining of pure delafossite, that is, delafossite without any secondary phases and impurities commonly reported during delafossite synthesis, such as iron oxides or metallic silver. Delafossite structure is also maintained for concentrations of Ag equal to $x=0.9$ and $x=0.8$. However, for the lower silver concentration peaks originating from secondary phases, that is, $\mathrm{Fe}_{2} \mathrm{O}_{3}$ and/or $\mathrm{FeOOH}$, are visible in the XRD patterns. Our results correspond well with published data; however, the authors of $[2,22,27]$ have obtained only one kind of secondary phase, $\mathrm{Fe}_{2} \mathrm{O}_{3}$ or $\mathrm{FeOOH}$. It is worth to mention that characteristic peak at about $2 \Theta=28.7^{\circ}$, derived from the main phase, that is, delafossite, is clearly visible in diffractograms for all the obtained $\mathrm{Ag}_{x} \mathrm{FeO}_{2}$ samples, which is shown in Fig. 2. 


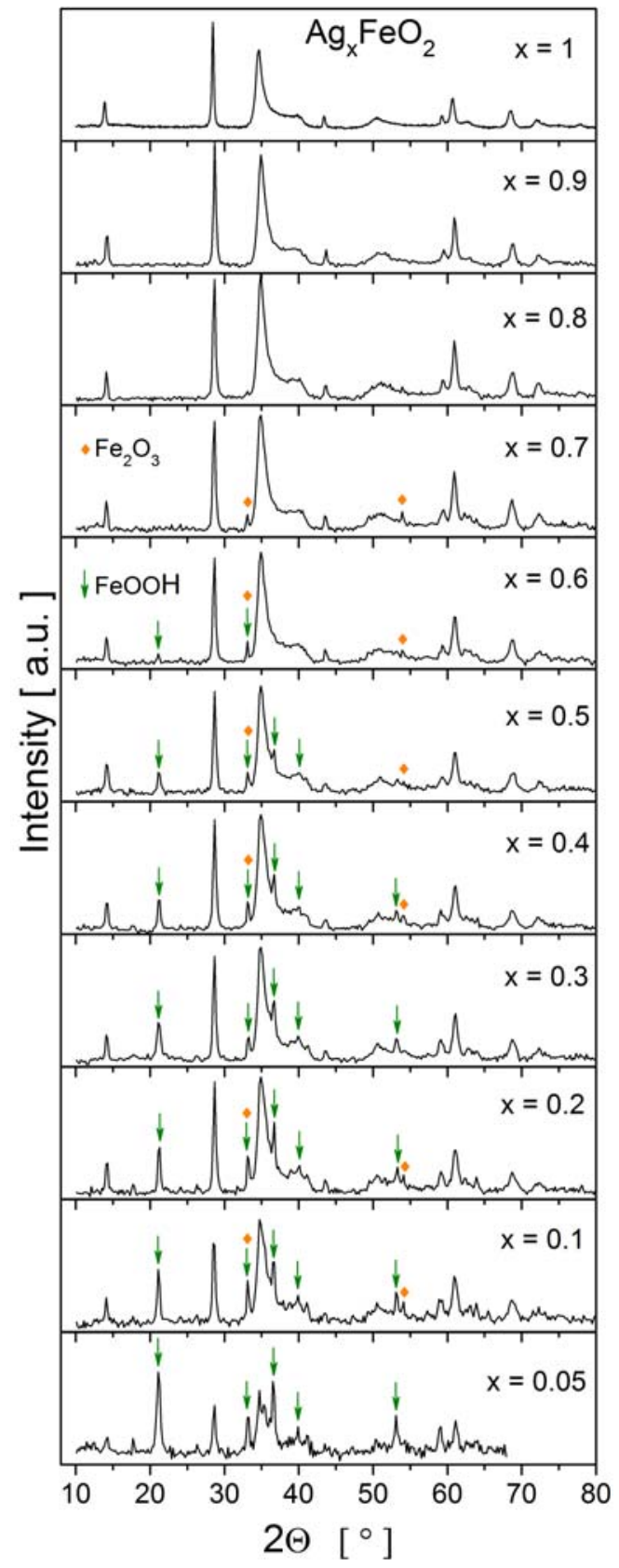

Fig. 2. XRD patterns for $\mathrm{Ag}_{x} \mathrm{FeO}_{2}$ delafossites in the range of Ag concentration $x=0.05-1$. Diffraction peaks from secondary phases are marked with arrows $-\mathrm{FeOOH}$ and diamonds $-\mathrm{Fe}_{2} \mathrm{O}_{3}$.

A detailed structural analysis of XRD pattern for stoichiometric $\mathrm{AgFeO}_{2}$ showed that both polytypes $3 R$ and $2 H$ are present in the obtained material; however, the contribution of $2 \mathrm{H}$ polytype was significantly larger. For all the samples of $\mathrm{Ag}_{x} \mathrm{FeO}_{2}$ series, the analysis was performed under an assumption that delafossite is the main phase and $2 \mathrm{H}$ polytype dominates. The unit cell dimensions of this phase determined from the XRD patterns are presented in Fig. 3. It may be observed that decreasing of $\mathrm{Ag}$ concentration (decreasing $x$ value from 1 to 0.05 ) causes the drop of both parameters of unit cell. The $a$ parameter is related to the geometry of $\mathrm{BO}_{6}$ octahedral layer; thus, the observed decrease in $a$ corresponds to the B-O bonds shortening. Additionally, since the $c$-axis parameter is strongly associated

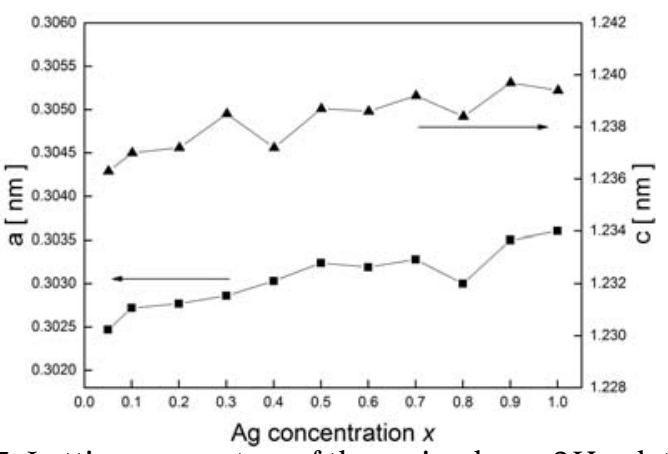

Fig. 3. Lattice parameters of the main phase, $2 H$ polytype vs. Ag concentration $x$ for $\mathrm{Ag}_{x} \mathrm{FeO}_{2}$ series.

with the O-A-O bonding, it is likely that an observed decrease in $c$ is related to an increase of the amount of A-site vacancies, which was also suggested in [2].

\section{Results of Mössbauer spectroscopy studies}

The recorded at room temperature Mössbauer spectra of synthesized samples are shown in Fig. 4.

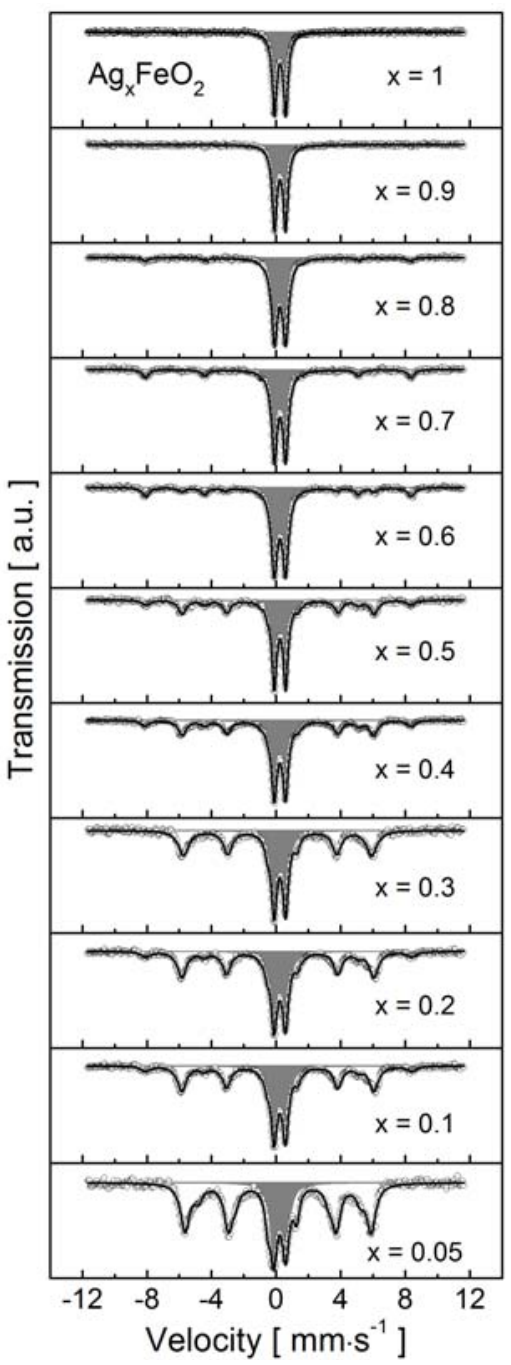

Fig. 4. Fitted room-temperature Mössbauer spectra of $\mathrm{Ag}_{x} \mathrm{FeO}_{2}$ delafossite powder samples in the range of silver concentration $x=0.05-1$. Component originating from $\mathrm{AgFeO}_{2}$ is market as grey doublet. Visible sextets come from $\mathrm{Fe}_{2} \mathrm{O}_{3}$ and $\alpha-\mathrm{FeOOH}$. 
Numerical fitting of the spectra was performed using discrete components method. It may be seen that for $x=0.9$ and 1 , the spectrum consists of one doublet while the remaining spectra are a superposition of doublet and sextets. The hyperfine interaction parameters for the components and the identification of phases are summarized in Table 1. Although in X-ray, in the diffraction pattern for a sample with $x=0.8$, no peaks from secondary phases are visible; while in the Mössbauer spectrum a subtle sextet is seen. The hyperfine interaction parameters of this component allowed us to identify tiny amount of hematite as secondary phase for $x=0.8$. The rest of the Mössbauer spectra consisted of one quadrupole doublet originating from the desired delafossite phase and two sextets from the secondary phases recognized as: $\mathrm{Fe}_{2} \mathrm{O}_{3}$ (sextet with $B_{\mathrm{hf}} \sim 51 \mathrm{~T}$ ) and/or $\mathrm{FeOOH}$ (sextet with $B_{\mathrm{hf}} \sim 37 \mathrm{~T}$ ) [29]. The amount of hematite and goethite systematically increases with a decrease in Ag concentration; the relative contributions shown in Table 1 were estimated from the area of spectral lines under an assumption of the same Lamb-Mössbauer coefficient for each component.

The hyperfine interactions parameters of the doublet are as follows: an isomer shift $\delta=$ $0.33-0.37 \mathrm{~mm} \cdot \mathrm{s}^{-1}$, and quadrupole splitting $\Delta=$
$0.68-0.73 \mathrm{~mm} \cdot \mathrm{s}^{-1}$. The obtained value of $\delta$ is typical for a high spin $\mathrm{Fe}^{3+}$ in the octahedral oxygen coordination. Rather high value of the quadrupole splitting means that strong electric field gradient appears in the $\mathrm{Fe}^{3+}$ position in crystalline lattice. The obtained results well agree with literature data [15].

As shown in Fig. 5, with a decrease in silver concentration, the hyperfine interaction parameters of the $\mathrm{AgFeO}_{2}$ doublet change slightly. It may be noted that there is a slight drop of isomer shift and inconsiderable rising of the quadrupole splitting. The first one results from crystalline lattice contraction and increase of the $s$-type electrons density within the volume of ${ }^{57} \mathrm{Fe}$ nuclei. The latter one may be associated both with reduction in volume of the unit cell and with rising amount of silver and oxygen vacancies.

\section{Conclusions}

It was shown that the simple co-precipitation method can be successfully applied to produce $\mathrm{Ag}_{x} \mathrm{FeO}_{2}$ silver delafossite with non-stoichiometric silver concentration in the range of $x=0.05-1$. Delafossite structure without secondary phases is maintained up to about $20 \%$ deficiency of $\mathrm{Ag}$ ions, which was

Table 1. Hyperfine interaction parameters derived from the numerical fitting of the MS spectra for $\mathrm{Ag}_{x} \mathrm{FeO} \mathrm{S}_{2}$ series; $\delta$ - isomer shift relative to $\alpha$-iron, $2 \varepsilon$ - quadrupole shift for the sextets (S1 and S2), $\Delta$ - quadrupole splitting for the doublet (D), $B_{\mathrm{hf}}$ - hyperfine magnetic field, $\chi^{2}$ - normalized variance of fitting, $A$ - relative contributions of components; uncertainties of the values are given for the last significant number in parentheses

\begin{tabular}{|c|c|c|c|c|c|c|c|c|}
\hline $\begin{array}{c}\mathrm{Ag} \\
\text { concentration }\end{array}$ & Component & $\begin{array}{c}\delta \\
{\left[\mathrm{mm} \cdot \mathrm{s}^{-1}\right]}\end{array}$ & $\begin{array}{c}\Delta \\
{\left[\mathrm{mm} \cdot \mathrm{s}^{-1}\right]}\end{array}$ & $\begin{array}{c}2 \varepsilon \\
{\left[\mathrm{mm} \cdot \mathrm{s}^{-1}\right]}\end{array}$ & $\begin{array}{l}B_{\mathrm{hf}} \\
{[\mathrm{T}]}\end{array}$ & $\chi^{2}$ & $\begin{array}{c}A \\
{[\%]}\end{array}$ & Phase \\
\hline$\overline{1.0}$ & $\mathrm{D}$ & $0.37(1)$ & $0.69(1)$ & - & - & 0.70 & 100 & $\mathrm{AgFeO}_{2}$ \\
\hline 0.9 & $\mathrm{D}$ & $0.35(1)$ & $0.68(1)$ & - & - & 0.96 & 100 & $\mathrm{AgFeO}_{2}$ \\
\hline 0.8 & $\begin{array}{l}\mathrm{D} \\
\mathrm{S} 1\end{array}$ & $\begin{array}{l}0.35(1) \\
0.36(1)\end{array}$ & $\begin{array}{c}0.69(1) \\
-\end{array}$ & $\begin{array}{c}- \\
0.26(1)\end{array}$ & $51 . \overline{0}(1)$ & 1.31 & $\begin{array}{r}93 \\
7\end{array}$ & $\begin{array}{c}\mathrm{AgFeO}_{2} \\
\mathrm{Fe}_{2} \mathrm{O}_{3}\end{array}$ \\
\hline 0.7 & $\begin{array}{l}\mathrm{D} \\
\mathrm{S} 1\end{array}$ & $\begin{array}{l}0.34(1) \\
0.35(1)\end{array}$ & $\begin{array}{c}0.69(1) \\
-\end{array}$ & $\begin{array}{c}- \\
0.21(1)\end{array}$ & ${ }_{51 .}^{-}$ & 1.01 & $\begin{array}{l}84 \\
16\end{array}$ & $\begin{array}{c}\mathrm{AgFeO}_{2} \\
\mathrm{Fe}_{2} \mathrm{O}_{3}\end{array}$ \\
\hline 0.6 & $\begin{array}{l}\text { D } \\
\text { S1 } \\
\text { S2 }\end{array}$ & $\begin{array}{l}0.34(1) \\
0.35(1) \\
0.35(1)\end{array}$ & $\begin{array}{c}0.69(1) \\
- \\
-\end{array}$ & $\begin{array}{c}- \\
0.18(1) \\
0.17(1)\end{array}$ & $\begin{array}{c}- \\
51.1(1) \\
37.1(1)\end{array}$ & 0.75 & $\begin{array}{r}74 \\
18 \\
8\end{array}$ & $\begin{array}{c}\mathrm{AgFeO}_{2} \\
\mathrm{Fe}_{2} \mathrm{O}_{3} \\
\mathrm{FeOOH}\end{array}$ \\
\hline 0.5 & $\begin{array}{l}\mathrm{D} \\
\mathrm{S} 1 \\
\mathrm{~S} 2\end{array}$ & $\begin{array}{l}0.35(1) \\
0.37(1) \\
0.38(1)\end{array}$ & $\begin{array}{c}0.70(1) \\
- \\
-\end{array}$ & $\begin{array}{c}- \\
0.19(1) \\
0.27(1)\end{array}$ & $\begin{array}{c}- \\
51.1(1) \\
37.0(1)\end{array}$ & 0.79 & $\begin{array}{l}59 \\
11 \\
30\end{array}$ & $\begin{array}{c}\mathrm{AgFeO} \\
\mathrm{Fe}_{2} \mathrm{O}_{3} \\
\mathrm{FeOOH}\end{array}$ \\
\hline 0.4 & $\begin{array}{l}\mathrm{D} \\
\mathrm{S} 1 \\
\mathrm{~S} 2\end{array}$ & $\begin{array}{l}0.34(1) \\
0.35(1) \\
0.36(1)\end{array}$ & $\begin{array}{c}0.69(1) \\
- \\
-\end{array}$ & $\begin{array}{c}- \\
0.23(1) \\
0.28(1)\end{array}$ & $\begin{array}{c}- \\
51.2(1) \\
36.9(1)\end{array}$ & 0.91 & $\begin{array}{l}55 \\
12 \\
32\end{array}$ & $\begin{array}{c}\mathrm{AgFeO}_{2} \\
\mathrm{Fe}_{2} \mathrm{O}_{3} \\
\mathrm{FeOOH}\end{array}$ \\
\hline 0.3 & $\begin{array}{l}\mathrm{D} \\
\mathrm{S} 2\end{array}$ & $\begin{array}{l}0.34(1) \\
0.34(1)\end{array}$ & $\begin{array}{c}0.70(1) \\
-\end{array}$ & $\begin{array}{c}- \\
0.28(1)\end{array}$ & $\begin{array}{c}- \\
36.2(1)\end{array}$ & 0.75 & $\begin{array}{l}47 \\
53\end{array}$ & $\begin{array}{l}\mathrm{AgFeO}_{2} \\
\mathrm{FeOOH}\end{array}$ \\
\hline 0.2 & $\begin{array}{l}\text { D } \\
\text { S1 } \\
\text { S2 }\end{array}$ & $\begin{array}{l}0.34(1) \\
0.37(1) \\
0.35(1)\end{array}$ & $\begin{array}{c}0.71(1) \\
- \\
-\end{array}$ & $\begin{array}{c}- \\
0.16(1) \\
0.27(1)\end{array}$ & $\begin{array}{c}- \\
51.3(1) \\
36.9(1)\end{array}$ & 0.76 & $\begin{array}{l}53 \\
12 \\
35\end{array}$ & $\begin{array}{c}\mathrm{AgFeO} \\
\mathrm{Fe}_{2} \mathrm{O}_{3} \\
\mathrm{FeOOH}\end{array}$ \\
\hline 0.1 & $\begin{array}{l}\text { D } \\
\text { S1 } \\
\text { S2 }\end{array}$ & $\begin{array}{l}0.33(1) \\
0.35(1) \\
0.35(1)\end{array}$ & $\begin{array}{c}0.70(1) \\
- \\
-\end{array}$ & $\begin{array}{c}- \\
0.16(1) \\
0.26(1)\end{array}$ & $\begin{array}{c}- \\
51.2(1) \\
37.0(1)\end{array}$ & 0.79 & $\begin{array}{r}46 \\
9 \\
45\end{array}$ & $\begin{array}{c}\mathrm{AgFeO}_{2} \\
\mathrm{Fe}_{2} \mathrm{O}_{3} \\
\mathrm{FeOOH}\end{array}$ \\
\hline 0.05 & $\begin{array}{l}\mathrm{D} \\
\mathrm{S} 2 \\
\end{array}$ & $\begin{array}{l}0.33(1) \\
0.36(1) \\
\end{array}$ & $\begin{array}{c}0.73(1) \\
- \\
\end{array}$ & $\begin{array}{c}- \\
0.25(1)\end{array}$ & $\begin{array}{c}- \\
35.3(1) \\
\end{array}$ & 2.52 & $\begin{array}{l}39 \\
61 \\
\end{array}$ & $\begin{array}{l}\mathrm{AgFeO}_{2} \\
\mathrm{FeOOH}\end{array}$ \\
\hline
\end{tabular}




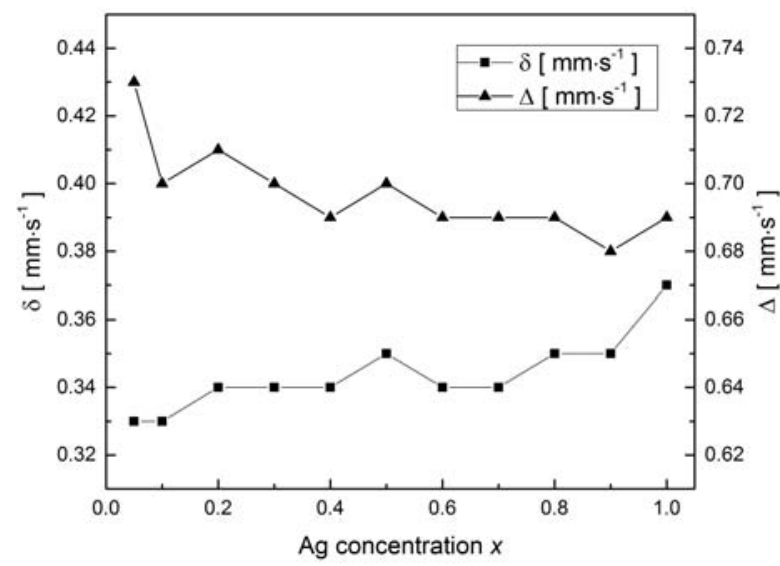

Fig. 5. Dependence of isomer shift and quadrupole splitting on decreasing $\mathrm{Ag}$ concentration for $\mathrm{AgFeO}_{2}$ delafossite doublet derived from numeric fitting of room-temperature Mössbauer spectra for $\mathrm{Ag}_{x} \mathrm{FeO}_{2}$ series.

confirmed both by X-ray diffraction and Mössbauer spectroscopy. For the lower silver concentration, in the obtained material except the main delafossite phase, secondary phases $\mathrm{Fe}_{2} \mathrm{O}_{3}$ and/or FeOOH precipitated. As proved by XRD studies, the lowering of silver concentration influenced the reduction of unit cell volume of $\mathrm{AgFeO}_{2}$, which was reflected in changes in the hyperfine interaction parameters, that is, a drop of isomer shift and an increase of quadrupole splitting.

\section{References}

1. Amrute, P., Larrazábal, G. O., \& Mondelli, C. (2013). $\mathrm{CuCrO}_{2}$ delafossite: A stable copper catalyst for chlorine production. Angew. Chem. Int. Ed., 52, 1-5. DOI: 10.1002/anie.201304254.

2. Durham, J. L., Kirshenbaum, K., Takeuchi, E. S., Marschilok, A. C., \& Takeuchi, K. J. (2015). Synthetic control of composition and crystallite size of silver ferrite composites: profound electrochemistry impacts. Chem. Commun., 51, 5120-5123. DOI: $10.1039 / \mathrm{c} 4 \mathrm{cc} 10277 \mathrm{k}$

3. Elsayed, I. A., Çavas, M., Gupta, R., Fahmy, T., AlGhamdi, A. A., \& Yakuphanoglu, F. (2015). Photoconducting and photocapacitance properties of $\mathrm{Al} / p$ $\mathrm{CuNiO}_{2}$-on- $p$-Si isotype heterojunction photodiode. J. Alloy. Compd., 638, 166-171. DOI: http://dx.doi. org/10.1016/j.jallcom.2015.02.212.

4. Liu, Y., Gong, Y., Mellott, N. P., Wang, B., Ye, H., \& Wu, Y. (2016) Luminescence of delafossite-type $\mathrm{CuAlO}_{2}$ fibers with Eu substitution for Al cations. Sci. Technol. Adv. Mater., 17, 200-209. DOI: 10.1080/14686996.2016.1172024.

5. Sun, H., Yazdi, M. A. P., Sanchette, F., \& Billard, A., (2016). Optoelectronic properties of delafossite structure $\mathrm{CuCr}_{0.93} \mathrm{Mg}_{0.07} \mathrm{O}_{2}$ sputter deposited coatings. J. Phys. D-Appl. Phys., 49, 185105(1-10). DOI: 10.1088/0022-3727/49/18/185105.

6. Tripathi, T. S., Niemelä, J. -P., \& Karppinen, M. (2015). Atomic layer deposition of transparent semiconducting oxide $\mathrm{CuCrO}_{2}$ thin films. J. Mater. Chem. $C, 3,8364-8371$. DOI: $10.1039 / \mathrm{c} 5 \mathrm{tc} 01384 \mathrm{~d}$.

7. Yu, M., Draskovic, T. I., \& Wu, Y. (2016). Cu(I)-based delafossite compounds as photocathodes in p-type dye-sensitized solar cells. Phys. Chem. Chem. Phys., 16, 5026-5033. DOI: 10.1039/c3cp55457k.
8. Amrute, A. A., Łodziana, Z., Mondelli, C., Krumeich, F., \& Perez-Ramirez, J. (2013). Solid-state chemistry of cuprous delafossites: Synthesis and stability aspects. Chem. Matter., 25, 4423-4435. DOI: 10.1021/ $\mathrm{cm} 402902 \mathrm{~m}$.

9. Prewitt, C. T., Shannon, R. D., \& Rogers, D. B. (1971). Chemistry of noble metal oxides. II. Crystal structures of $\mathrm{PtCoO}_{2}, \mathrm{PdCoO}_{2}, \mathrm{CuFeO}_{2}$, and $\mathrm{AgFeO}_{2}$. Inorg. Chem., 10, 719-723. DOI: 10.1021/ic50098a012.

10. Sheets, W. C., Mugnier, E., Barnabé, A., Marks, T. J., \& Poeppelmeier, K. R. (2006). Hydrothermal synthesis of delafossitetype oxides. Chem. Mater., 18, 7-20. DOI: $10.1021 / \mathrm{cm} 051791 \mathrm{c}$

11. Marquardt, M. M., Ashmore, N. A., \& Cann, D. P. (2006). Crystal chemistry and electrical properties of the delafossite structure. Thin Solid Films, 496, 146-156. DOI: 10.1016/j.tsf.2005.08.316.

12. Krause, A., \& Gawryck, S. (1938). Amorphe und kristallisierte Oxydhydrate und Oxyde. XLIV. Die Umwandlung des röntgenographisch amorphen Eisen III-hydroxyds in $\gamma-\mathrm{Fe}_{2} \mathrm{O}_{3}$. Z. Anorg. Allg. Chem., 238, 406-412. DOI: 10.1002/zaac.19382380409.

13. Krause, V. A., \& Lewandowski, A. (1972). Bildung von Silberferriten aus Silberoxid- und Eisen(III) hydroxidGelen in wäßrigem Medium. Z. Anorg. Allg. Chem., 389(1), 71-74. DOI: 10.1002/ zaac. 19723890109 .

14. Shannon, R. D., Rogers, D. B., \& Prewitt, C. T. (1971). Chemistry of noble metal oxides. I. Syntheses and properties of $\mathrm{ABO}_{2}$ delafossite compounds. Inorg. Chem., 10, 713-719. DOI: 10.1021/ic50098a011.

15. Presniakov, I. A., Rusakov, V. S., Sobolev, A. V., Gapochka, A. M., Matsnev, M. E., \& Belik, A. A. (2014). ${ }^{57} \mathrm{Fe}$ Mössbauer study of new multiferroic $\mathrm{AgFeO}_{2}$. Hyperfine Interact., 226, 41-50. DOI: 10.1007/s10751-013-0948-9.

16. Rusakov, V. S., Presniakov, I. A., Sobolev, A. V., Gapochka, A. M., Matsnev, M. E., \& Belik, A. A. (2013). Spatially modulated magnetic structure of $\mathrm{AgFeO}_{2}$ : Mössbauer study on ${ }^{57} \mathrm{Fe}$ nuclei. JEPT Lett+, 98, 544-550. DOI: 10.1134/S0021364013220098.

17. Terada, N., Khalyavin, D. D., Manuel, P., Tsujimoto, Y., \& Belik, A. A. (2015). Magnetic ordering and ferroelectricity in multiferroic $2 \mathrm{H}-\mathrm{AgFeO}_{2}$ : Comparison between hexagonal and rhombohedral polytypes. Phys. Rev. B, 91, 094434(17). DOI: http://dx.doi. org/10.1103/PhysRevB.91.094434.

18. Terada, N., Khalyavin, D. D., Manuel, P., Tsujimoto, Y., Knight, K., Radaelli, P. G., Suzuki, H. S., \& Kitazawa, H. (2012). Spiral-spin-driven ferroelectricity in a multiferroic delafossite $\mathrm{AgFeO}_{2}$. Phys. Rev. Lett., 109, 097203(5pp.). DOI: http://dx.doi.org/10.1103/ PhysRevLett.109.097203.

19. Vasiliev, A., Volkova, O., Presniakov, I. A., Baranov, A., Demazeau, G., Broto, J. -M., Millot, M., Lepts, N., Klingeler, R., Büchner, B., Stone, M. B., \& Zheludev, A. (2010). Thermodynamic properties and neutron diffraction studies of silver ferrite $\mathrm{AgFeO}_{2}$. J. Phys.-Condens. Matter, 22, 016007 (6pp.). DOI: 10.1088/0953-8984/22/1/016007.

20. Gong, H., Wang, Y., \& Luo, Y. (2000). Nanocrystalline p-type transparent $\mathrm{Cu}-\mathrm{Al}-\mathrm{O}$ semiconductor prepared by chemical-vapor deposition with $\mathrm{Cu}(\mathrm{acac})_{2}$ and $\mathrm{Al}(\mathrm{acac})_{3}$ precursors. Appl. Phys. Lett., 76, 3959-3961. DOI: http://dx.doi.org/10.1063/1.126834.

21. Tsuboi, N., Takahashi, Y., Kobayashi, S., Shimizu, H., Kato, K., \& Kaneko, F. (2003). Delafossite $\mathrm{CuAlO}_{2}$ films prepared by reactive sputtering using $\mathrm{Cu}$ and $\mathrm{Al}$ targets. J. Phys. Chem. Solids, 64, 1671-1674. DOI: 10.1016/S0022-3697(03)00194-X. 
22. Yanagi, H., Kawazoe, H., Kudo, A., Yasukawa, M., \& Hosono, H. (2000). Chemical design and thin film preparation of $p$-type conductive transparent oxides. J. Electroceram., 4, 407-414. DOI: 10.1023/A:1009959920435.

23. Chonco, Z. H., Ferreira, A., Loyda, L., Claeys, M., \& Van Steen, E. (2013). Comparing silver and cooper as promoters in Fe-based Fischer-Tropsch catalysts using delafossite as a model compound. J. Catal., 307, 283-294. DOI: http://dx.doi.org/10.1016/j. jcat.2013.08.005.

24. Farley, K. E., Marschilok, A. C., Takeuchi, E. S., \& Takeuchi, K. J. (2012). Synthesis and electrochemistry of silver ferrite. Electrochem. Solid State, 15(2), A23-A27. DOI: 10.1149/2.010202esl.

25. Krehula, S., \& Musić, S. (2013). Formation of $\mathrm{AgFeO}_{2}, \alpha-\mathrm{FeOOH}$, and $\mathrm{Ag}_{2} \mathrm{O}$ from mixed $\mathrm{Fe}\left(\mathrm{NO}_{3}\right)_{3^{-}}$ $\mathrm{AgNO}_{3}$ solutions at high pH. J. Mol. Struct., 1044,
221-230. DOI: http://dx.doi.org/10.1016/j.molstruc.2012.11.012.

26. Murthy, Y. L. N., Kondala Rao, T., Kasiviswanath, I. V., \& Singh, R. (2010). Synthesis and characterization of nano silver ferrite composite. J. Magn. Magn. Mater., 322, 2071-2074. DOI: 10.1016/j.jmmm.2010.01.036.

27. Nagarajan, R., \& Tomar, N. (2009). Ultrasound assisted ambient temperature synthesis of ternary oxide $\mathrm{AgMO}_{2}(M=\mathrm{Fe}, \mathrm{Ga})$. J. Solid State Chem., 182, 1283-1290. DOI: 10.1016/j.jssc.2009.01.043.

28. Wang, X., Shi, Z., Yao, S., Liao, F., Ding, J., \& Shao, M. (2014). Gamma ray irradiated $\mathrm{AgFeO}_{2}$ nanoparticles with enhanced gas sensor properties. J. Solid State Chem., 219, 228-231. DOI: http://dx.doi. org/10.1016/j.jssc.2014.07.024.

29. Cornell, R. M., \& Schwertmann, U. (1996). The iron oxides. Structure, properties, reactions, occurrence and uses. Weinheim: Wiley-Verlag Chemie. 